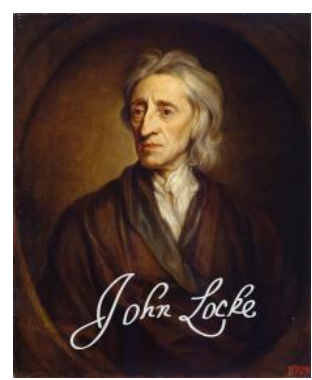

LOCKE STUDIES

Vol. 14

https://doi.org/10.5206/ls.2014.732 | ISSN: 1476-0290

Originally published: 2014

Published online: 19 FEBRUARY 2018

(C) Locke Studies, 2014

\title{
Locke and Wilkins on Inner Sense and Volition
}

\author{
PATRICK CONNOLLY (IOWA STATE UNIVERSITY)
}

Recommended citation:

Connolly, Patrick. "Locke and Wilkins on Inner Sense and Volition." Locke Studies 14 (2014): 239-259.

https://doi.org/10.5206/ls.2014.732

For more information about this article:

https://ojs.lib.uwo.ca/index.php/locke/article/view/732

Locke Studies is published by The John Locke Society.

This is an open access article published under the terms of the Creative Commons AttributionNonCommercial-ShareAlike 4.0 International license, which permits use, distribution and reproduction in any medium, provided the original work is properly cited and shared under the original license. 


\title{
LOCKE AND WILKINS \\ ON INNER SENSE AND VOLITION
}

\author{
PATRICK CONNOLLY
}

\section{Introduction}

The primary purpose of this paper is to elucidate two interesting parallels between views discussed in John Wilkins's Of the Principles and Duties of Natural Religion (hereafter Principles) and positions developed by John Locke in his Essay concerning Human Understanding (hereafter Essay). The first parallel pertains to a faculty of inner sense. Both authors carve out a central role for this introspective perceptual modality. The second parallel pertains to volition and free will. Both authors employ an investigative methodology which privileges first-personal experiences of choosing and willing. ${ }^{1}$

The paper will proceed as follows. First, I will briefly discuss Wilkins's life and work. The next two sections will discuss internal sense and voluntary action, respectively. In both sections I will first examine the doctrines found in Wilkins's Principles and then discuss how they relate to the complementary views found in Locke's Essay. Following this I will discuss the deep connection between inner sense and an 'experimental' approach to the will and explain how adoption of the first paved the way

${ }^{1}$ Most of the literature discussing Locke and Wilkins has focused on points of divergence. The views of the two authors on language and Locke's antipathy towards universal language schemes like Wilkins's have been discussed by Thompson 1980, Dawson 2007, and Slaughter 2010. Ferreira 1986a and Ferreira 1986b, chapter 2 analyze the way in which Locke and Wilkins disagreed about epistemic categories like probability and certainty. Yolton 1956, 38, notes that Wilkins may have been among the nativists targeted in Book I of Locke's Essay. (Yolton may be correct, but see Shapiro 1969, 235, for an interesting discussion of Wilkins's nativism in light of Locke's views.) One author who has tried to draw a positive connection between Locke and Wilkins is Grant McColley. His 1938 discussion note focuses on empiricism and scientific method in the two thinkers. But McColley's discussion is very brief and does not mention inner sense, volition, or Wilkins's Principles. 
for adoption of the second. Before concluding I will consider the significance of this parallel between the two thinkers.

\section{John Wilkins}

Wilkins was born in 1614. He was educated at Magdalen Hall, Oxford and remained in Oxford until 1637 when he entered the ministry. He first served as private chaplain to influential aristocrats and then as a preacher at Gray's Inn. Wilkins returned to Oxford in 1648 to become the Warden of Wadham College, a position he would hold for a decade. By this stage, Wilkins had already published works intended to popularize elements of the 'new science', but in Oxford this interest in natural philosophy burgeoned. John Aubrey reports that 'He was the principal reviver of experimental philosophy (in the spirit of Lord Bacon) at Oxford, where had had weekly an experimental philosophical club, which began in 1649, and was the cradle of the Royal Society'. The Wadham circle was indeed central to the advances in natural philosophy that were then occurring in Oxford. And a number of important natural philosophers (e.g. Boyle, Hooke, Willis, and Wallis) attended these meetings. ${ }^{3}$

Wilkins left Oxford in 1659. He served briefly as Master of Trinity College, Cambridge, before occupying a number of ecclesiastical positions. He spent most of the 1660s living in London. The origins of the Royal Society are much more complicated than Aubrey allows, but it is certainly true that Wilkins was a highly influential early member of the organization. In the 1660s Wilkins also became interested in language and linguistics. He was particularly intrigued by the possibility of creating a universal language. These interests culminated in the publication of his Essay Towards a Real Character and a Philosophical Language (London, 1668). In

2 Aubrey 1982, 325.

3 See Frank 1980 for a much more detailed discussion of Oxford natural philosophy and the Wadham circle. See also Feingold 1997 and Frank 1997. 
1668 Wilkins was appointed Bishop of Chester, a position he would hold until his death in $1672 .^{4}$

At the time of his death Wilkins was working on the Principles. This work was published posthumously in 1675 after being edited for the press by Wilkins's friend John Tillotson. It seems to have been well received and went through at least eleven editions between its initial publication and $1734 .^{5}$ The purpose of the book is threefold. It is intended (1) to convince readers of the existence of God, the principles of natural religion, and the existence of an afterlife, (2) to appraise readers of their moral duties, and (3) to persuade readers to practice religion. In having these aims the work is largely unremarkable; it is of interest primarily because of its content. Wilkins argued that only limited certainty could be gained in many important religious matters and that only a very small set of beliefs was required for salvation. ${ }^{6}$ Most commentators have characterized the work as a statement of broadly latitudinarian Anglican principles. ${ }^{7}$

\section{Inner Sense}

Locke's views about inner sense are often thought to be among his most interesting and innovative. ${ }^{8}$ Further, Locke is often

4 For more on Wilkins's life see Shapiro 1969, Henry 2000, and Henry 2004. An anecdote too compelling to omit: on his deathbed Wilkins reportedly claimed that he was 'prepared for the great experiment'.

5 Editions were printed in 1675, 1676, 1678, 1683, 1693, 1699, 1704, 1710, 1715, 1722, and 1734.

6 There are, of course, obvious parallels here to themes in Locke's Reasonableness of Christianity and Book IV of the Essay.

7 McAdoo 1965, 203-31; Shapiro 1969, 233-45; Henry 2000, 889, 891-92; and Henry 2004. For a sceptical treatment of the explanatory usefulness of the term 'latitudinarian', see Spurr 1988.

8 For example, the Stanford Encyclopedia of Philosophy article on 'Self-Knowledge' describes Locke as 'an early champion of the Inner Sense model' (Gertler 2011, § 2.2). For discussions of Locke on inner sense see Kulstad 1984, Mishori 2004, Lähteenmäki 2008, Scharp 2008, and Thiel 2011. Thiel 2011, 110, very briefly mentions the 
understood as securing a place for inner sense within the empiricist tradition; the faculty of inner sense would later be developed in greater detail by Hume and other Scottish writers and would, ultimately, be given a very important role in Kant's philosophy. ${ }^{9}$ My goal in this section is to show that Locke was not entirely original in his theory of inner sense and that a very similar presentation can be found in the work of another member of his intellectual milieu. ${ }^{10}$ Specifically, I will present Wilkins's theory of inner sense and then examine its parallels to Locke's theory.

There are two central features of the inner sense described by Wilkins. The first pertains to the nature of this inner sense. Wilkins's claim is that it is directly comparable to outer sensation. The second central feature is what this inner sense gives us access to. Wilkins's claim is that it alerts us to the contents and the operations of the mind. I will discuss both of these in turn.

In describing the inner sense which he attributes to human beings, Wilkins makes explicit appeal to the more familiar category of outer sense. In his first description of this inner sense he begins by defining 'sense' more generally. He writes that 'By Senses I mean those faculties whereby we are enabled to discern and know such particular objects as are present'. ${ }^{11} \mathrm{He}$ then suggests that there are two such faculties. The first is the familiar category of outer sense: '1. Outward, by which we can apprehend external objects, as when we see, or hear, or touch anything

connection to Wilkins. Of course, the precise content of Locke's views is debated. But the differences between interpretations are irrelevant to the broader parallel I am highlighting in this paper.

9 For a discussion of the relationship between Locke and Kant on the inner sense see Kitcher 2011, ch. 2.

10 See Sams 1943 for a similar contention, although Sams does not mention Wilkins.

11 Wilkins 1675,3 . All quotations will be from this, the first edition of Wilkins's Principles. This was the edition owned by Locke. 
presented to us'. ${ }^{12}$ Wilkins elides smell and taste, but he is clearly referring to our ability to perceive external objects through our sensory organs.

The second sense faculty, the one which concerns us here, is the inner sense. Here is Wilkins's description:

2. Inward, by which we can discern internal objects, and are conscious to our selves, or sensible both of the impressions that are made upon our outward senses, and of the inward motions of our minds; namely, our apprehensions, inclinations, and the power of determining our selves, as to our own Actions; and by which we can at any time be assured of what we think, or what we desire, or purpose. ${ }^{13}$

So the inner sense is similar to outer sense insofar as it allows us perceptual access to something. That is one reason it is appropriate to call both of these distinct faculties 'senses'. Later in the Principles Wilkins again finds it helpful to explain the inner sense by direct comparison to outer sense. In explaining how it is that humans come to share similar ideas Wilkins writes that 'I shall therefore take this occasion to suggest briefly, that which to me seems the most easie and natural way for the explaining of this, namely, by comparing the inward sensation of our minds and understandings, with that of our outward senses'. 14

So it is because our inner sense operates in a manner similar to our outer sense that the two are classified together as senses. But what distinguishes these two? Why are they distinct? The answer to this question brings us to the second important feature of the inner sense: what it gives us access to. Outer sense is distinct from inner sense insofar as it gives us access to different things. While the outer sense alerts us to the existence and features of objects in the external world, the inner sense alerts us to the

12 Wilkins 1675,3 .

13 Ibid.

14 Wilkins 1675, 56. 
contents and operations of the mind. Wilkins describes it in one place as 'that kind of inward Sensation, whereby we can discern the impression of our own minds'. 15

We have already seen some intimation of this in Wilkins's initial introduction of the two faculties, in the passage quoted above. He writes that our outer sense gives us access to 'external objects'. By contrast, the inner sense gives us access to (1) the impressions from outer sense and (2) 'the inward motions of our minds'. Later in the work we get a more detailed account of what the inner sense provides access to. Wilkins writes that 'Now as there is universal agreement in the sensation of outward objects; The Eye and the Ear of all sensitive Creatures having the same kind of perception of visible and audible things. Those things which appear Green, Blew, or Red to one, having the same appearance to all others'. ${ }^{16}$ Then, moving from the outer sense to the inner, he continues: "So must it be with the understanding of men likewise, which do agree in the same kind of Perception or simple Apprehension of intelligible objects'. ${ }^{17}$ He continues:

And as in the making of Propositions, or compounding our Apprehensions about sensible things, we determine that the Green in this object is like the Green in that other, and unlike the Yellow or Blew in a third; That it is more, or less, or equal to something else, with which we compare it: So likewise it is for compounding other simple notions belonging to the understanding, By which we judg one thing to be like or unlike, agreeable or disagreeable, equal, or more or less, in respect to something else compared with it. ${ }^{18}$

So according to Wilkins the inner sense tells us, in the first place, about the contents of the mind. The contents can be purely

15 Wilkins $1675,92$.

${ }^{16}$ Wilkins $1675,56-57$.

17 Ibid.

18 Ibid. 
sensory, as when we are 'sensible... of the impressions that are made upon our outward senses'. And we can also have inner perceptions of what Wilkins calls 'intelligible objects'. But the contents can also be more complex. The inner sense gives us access to mental contents that are propositional. For example, it is responsible for allowing us to realize that two things are similar or that one is greater than another. So it is through the inner sense that we gain access to the contents of our mind. But Wilkins also maintains that the inner sense informs us about the operations of the mind. When the mind desires something, considers something, wills something, judges that something is the case, or engages is some reasoning process, Wilkins thinks it is the inner sense which makes us aware of these actions.

Locke devotes more attention and space to discussion of the inner sense than Wilkins. But I think it is clear that the two central features of Wilkins's discussion are present in Locke's discussion. We can first examine Locke's likening of inner sense to outer sense before examining Locke's views on what the inner sense gives us access to. In Book I of the Essay Locke attacks the view that any of our ideas are innate. Thus, at the outset of Book II Locke is in the position of needing to show where our ideas do come from. To do this, Locke makes a distinction similar to Wilkins's.

Locke writes that there are two sources of ideas. The first he calls 'sensation'. This category matches up to Wilkins's outward sensation. The second category, which Locke calls 'reflection', is the one that concerns us here. Just like Wilkins, Locke makes an analogy to outward sensation to present this category: 'This Source of Ideas, every Man has wholly in himself: And though it be not Sense, as having nothing to do with external Objects; yet it is very like it, and might properly enough be call'd internal Sense'. ${ }^{19}$ So, just as in Wilkins, there is an explicit appeal to outward sensation to define inner sense.

19 Locke 1975, II. i. 4, 105. 
Locke and Wilkins also agree on what this inner sense gives us access to. Locke writes that 'Our Observation employ'd either about external, sensible Objects; or about the internal Operations of our Minds, perceived and reflected on by our selves, is that, which supplies our Understandings with all the materials of thinking. ${ }^{20}$ Two sections later Locke gives a slightly different formulation, where he characterizes reflection as that which gives us access to 'the Operations of our own Minds within us, as it is employ'd about the Ideas it has got'. ${ }^{21}$ Thus, for Locke our sensory faculty is divided in two. One component, sensation, gives us access to external things, and the other component, reflection, gives us access to the contents and workings of our minds.

So Locke and Wilkins display a similarity insofar as both carve out a place for inner sense. They both develop the category through an explicit parallel to outer sense and they agree on the role of inner sense and what it provides us with information about.

\section{Voluntary Action}

In his survey of British debates over free will and voluntary action in the eighteenth century James Harris has argued that what unified participants in these debates was a shared commitment to a certain experimental methodology. ${ }^{22}$ What this means is that participants in these debates agreed that the facts about free will turned on features of our mental life that were introspectively available. First-personal examination, rather than

${ }^{20}$ Locke 1975, II. i. 2, 104. Slightly later in the chapter (at II. i. 4, 105-6) Locke clarifies what he means by operations: 'The term Operations here, I use in a large sence, as comprehending not barely the Actions of the Mind about its Ideas, but some sort of Passions arising sometimes from them, such as is the satisfaction or uneasiness arising from any thought'.

21

II. i. 4.

22 See Harris 2005, esp. 1-18. 
considerations about the metaphysical entities involved or analysis of relevant concepts, was taken to be essential. Although participants in these debates put forth contradictory theories about the will, they did agree on the proper way to approach the issue. That is to say that this 'experimental' approach to the will was endorsed by libertarians, compatibilists, and necessitarians alike.

Harris traces this methodology back to the one employed by Locke in his discussion of free will and voluntary action. I agree with Harris that Locke's chapter 'Of Power' was very much the starting point for eighteenth century debates about free will. ${ }^{23}$ And I agree that the methodology employed by Locke in that chapter was picked up by later participants in the debate. My contention, however, is that the embrace of this methodology extends backward from Locke's Essay, as well as forward. ${ }^{24}$ Specifically, I will argue that Wilkins employed this methodology in his discussion of free will and voluntary action. ${ }^{25}$

Wilkins's employment of this methodology is non-trivial. Certainly this had not always been the methodology employed in such debates and it was not the methodology found in many other treatments of the topic in 17 th century Britain. The strategy of exploring the phenomenological or introspectively available facts differs greatly from the metaphysical approach employed by

23 John Yolton put the point nicely at the outset of a chapter on 'The Concept of Action': 'As with so many of the topics discussed by eighteenth-century philosophers in Britain, Locke's statement of them frequently set the framework for their pursuit. His discussions of power, of liberty, of the person, and of action are echoed and cited'. See Yolton 1983, 127.

24 Note that my claim is about a methodology regarding free will that is shared by Locke and Wilkins, not about a position that is shared. Wilkins seems inclined towards a version of libertarianism. Locke, by contrast, seems much more comfortable with a form of compatibilism. For my purposes, however, this disagreement is less important than their agreement on a methodology. For substantive discussions of Locke's views on volition and agency see Yaffe 2000 and LoLordo 2012, esp. §1.

25 Note that I only mean to argue that Wilkins employs this methodology, not that he originates it. 
Hobbes and Bramhall in their famous dispute. ${ }^{26}$ It also differs greatly from the deeply theological approach to the topic seen in works like Peter Sterry's Discourse of the Freedom of the Will (1675). And in current debates about free will this experimental approach seldom takes center stage.

As mentioned above, Wilkins's Principles is not a work primarily concerned with matters of metaphysics and epistemology. Nevertheless, Wilkins is very much concerned with the will. One of the primary goals of the Principles is to convince readers that there is a moral law to which they are accountable. But, as Wilkins explains, humans can only be held accountable for their free actions: 'Rewards and Punishments do properly belong to free Actions, such as are under man's power, either to do or forebear; not to such as are necessary'. ${ }^{27}$ Because there is a tight connection between voluntary action and moral responsibility Wilkins is deeply concerned with what he describes as a 'Faculty whereby [man] is enabled to chuse and prosecute such things as may promote [his] end, and to reject and avoid such things as may hinder it'. ${ }^{28}$

That someone primarily concerned with issues of theology and punishment should be concerned with issues relating to free will and voluntary action is in itself unremarkable. What is interesting in Wilkins's discussion of this topic is the experimental approach he employs. Recall from above that, according to Wilkins, one of the things we are 'sensible' of is 'the power of determining our

26 Admittedly, Hobbes does, on occasion, hint at the importance of experience for the dispute. He suggests at one point that in these matters there 'can no other proof be offered but every man's own experience, by reflection on himself'. See Hobbes and Bramhall 1999, 39. But appeal to experience is not Hobbes's main strategy. In general Hobbes relies on physical and metaphysical considerations; he emphasizes the nature of causation and necessity to argue that an undetermined action is impossible and thereby to put pressure on Bramhall's libertarian position.

\footnotetext{
27 Wilkins 1675, 31.

28 Wilkins $1675,82$.
} 
selves, as to our own Actions'. ${ }^{29}$ A later passage is even more explicit:

Nothing can be more manifest and plain to me, than that I now see somewhat which hath the appearance of such a colour or figure, than that I have in my mind such a thought, desire, or purpose, and do feel within my self a certain power of determining my own actions, which is called Liberty. ${ }^{30}$

Wilkins continually seeks to highlight our introspective access to the acts of our will. It is by reflecting on our personal experiences of deliberating and choosing that we will come to understand the will.

This distinctive, first-personal, approach to questions of free will is most in evidence when Wilkins briefly considers an argument for necessitarianism.

Now the Laws of Matter are necessary, there can be no $\alpha v \tau \varepsilon \xi o v$ бıvv, or arbitrary principle in meer matter. And it is worth observation, how this very argument puzzled Epicurus and his followers, as is represented by Lucretius. If all material things move by necessary Laws, and the parts of Matter be naturally so dispos'd, that they do not move unless they be moved, and cannot but move when press'd upon by other parts that are in motion; whence comes that liberty which we may by an inward sensation perceive to be within us?

Wilkins is unimpressed with this Epicurean line of thought. For Wilkins, the seemingly convincing claim that matter only moves after contact with other matter is obviously defeated in the face of the incontrovertible evidence of our freedom that we get from introspection (from our 'inward sensation').

\footnotetext{
29 Wilkins $1675,3$.

30 Wilkins $1675,5-6$.

31 Wilkins 1675, 107-8.
} 
A similar attitude is evinced when Wilkins argues that our ignorance of the mechanism by which our will operates is no obstacle to our believing that we do sometimes act freely. His claim is that our lived experience of acting is enough to dismiss doubts about our freedom: 'To say that we cannot tell whether we have Liberty because we do not understand the manner of Volition, is all one as to say, That we cannot tell whether we see or hear, because we do not understand the manner of sensation, ${ }^{32}$ Wilkins is fond of this argument is its more general form as well:

To which I shall only add, that we may be unquestionably sure of many things as to their existence, and yet we may not be able to explain the nature of them. No man in his wits can make any doubt, whether by such things as Motion, and Sensation, and Continuity of Bodies: And yet these things are commonly esteemed inexplicable. So that our not being able to see to the bottom of things, and to give a distinct account of the nature and manner of them, can be no sufficient cause to doubt of their being. ${ }^{33}$

So Wilkins not only thinks that an examination of our experiences is the correct way to settle questions about free will, he thinks these experiences have a high epistemic status and is happy to let them do significant philosophical work.

When we turn to Locke we see that he also takes our experiences of willing as a starting point for a discussion of free will. Locke initiates his discussion of free will at II. xxi. 5 by noting that 'we find in our selves a Power to begin or forbear, continue or end several actions of our minds, and motions of our Bodies, barely by a thought or preference of the mind ${ }^{34}$ The 'finding in oneself' language is repeated at II. xxi. 7. At II. xxi. 15 he offers the caveat that 'I must here warn my Reader that

32 Wilkins 1675, 6. Note in this passage the comparison between external perception of objects and internal perception of the will.

33 Wilkins 1675, 26-27.

34 Locke 1975, II. xxi. 5, 236 (emphasis added). 
Ordering, Directing, Chusing, Preferring, etc. which I have made use of, will not distinctly enough express Volition, unless he will reflect on what he himself does, when he wills'. ${ }^{35}$ So Locke and Wilkins agree that the proper way to approach the topic of the will is to analyze our lived experiences of willing various actions.

Locke also confessed ignorance about the mechanism by which the will operates, but thought this was unimportant given the experiential evidence of its efficacy. At II. xxiii. 28 Locke is puzzling over how matter can transfer motion to other matter by impulse. He suggests that the mystery here is akin to the one of how our wills can create motion in our bodies ('which we every moment find they do'). As for the mechanisms at work, Locke thinks that on both these topics 'we are equally in the dark'. But Locke is not worried about this metaphysical difficulty. He thinks it is sufficient that we have experiences of our thought actually sufficing to move our bodies: 'the Mind, every day, affords us Ideas of an active power of moving of Bodies' and 'Constant Experience makes us sensible' of this.

\section{The Connection Between Internal Sense and Volition}

Up until now I have considered inner sense and volition as distinct topics. And I have suggested that these are two distinct parallels between the views Wilkins espouses in the Principles and those Locke develops in the Essay. I do believe that these are distinct topics and I think it is correct to suggest that they are distinct parallels. But I also want to say something about what I see as the tight connection between them. Specifically, I want to suggest that the methodology employed by Wilkins and Locke in their treatment of volition and free action was abetted by their recognition of a robust inner sense.

\footnotetext{
35 Locke 1975, II. xxi. 15, 240.

36 Locke 1975, II. xxiii. 28, 311.

37 Ibid., 311-12.
} 
The experimental methodology discussed in the previous section is predicated on the idea that introspective analyses of our acts of deliberation and choice can give us insight into our volitional faculty. One might wonder, however, why Locke and Wilkins (and subsequent authors) thought that this was a good strategy. Why not begin by analyzing the concept of 'freedom' or by considering the implications of free will for morality or physics? Why prefer this introspective methodology? One relatively straightforward answer might appeal to an inner sense. If one thought the inner sense played a central role in our cognition, then the thought that questions of free will could be settled by an analysis of our volitional experiences seems highly plausible.

Examining Locke and Wilkins's remarks on this should help elucidate this thought. Recall Wilkins's claim that 'Nothing can be more manifest and plain to me, than that I now see somewhat which hath the appearance of such a colour or figure, than that I have in my mind such a thought, desire, or purpose, and do feel within my self a certain power of determining my own actions, which is called Liberty'. ${ }^{38}$ In this passage, Wilkins is equating the obviousness of our free will with the obviousness of our immediate perceptual experiences of external objects. Our access to colors and shapes is excellent, thanks to our outward sense. Similarly, our access to facts about free will is excellent, thanks to our inner sense.

We get a similar view in Locke. Locke's initial discussion of the ideas we receive from reflection, that is to say, from our inner sense, comes at II. vi. Here Locke writes that 'The two great and principal Actions of the Mind, which are most frequently considered, and which are so frequent, that every one that pleases, may take notice of 'em in himself, are these two: Perception, or Thinking, and Volition, or Willing'. 39 Examining Locke's initial

38 Wilkins $1675,5-6$.

39

Locke 1975, II. vi. 2, 128. 
list of operations of the mind which reflection gives us access to is also telling: 'and such are, Perception, Thinking, Doubting, Believing, Reasoning, Knowing, Willing, and all the different actings of our own Minds' ${ }^{40}$ So Locke also clearly believed that the will was something we have a distinct sort of access to in virtue of our inner sense.

\section{The Connection Between Locke and Wilkins}

In the previous sections I have shown that the treatments of inner sense and volition that Locke and Wilkins give in their respective works bear a marked similarity to one another. It is now worth asking what the significance of this similarity is.

One natural question to ask is whether the views found in the Essay were influenced by those found in the Principles. ${ }^{41}$ Locke was exposed to some of Wilkins's writings and did own a copy of the Principles. ${ }^{42}$ And, on the whole, I think we can safely assume that Locke would have appreciated Wilkins's larger natural philosophical agenda and the generally latitudinarian positions developed in the Principles. That said, it seems that the views in the Essay were not directly influenced by the Principles. Locke's

40

Locke 1975, II. i. 4, 105 (emphasis added).

41 Of course, the Principles is hardly the only possible influence for Locke's views on these two issues. Introspection had long been a part of philosophical theorizing and had proponents earlier in the seventeenth century. As briefly noted above, Hobbes did not think that introspection was entirely irrelevant to debates over free will, even if it does not play a central role in his argument. And Hobbes did allow for some sort of inner sense, although it never plays a significant role in his theory of mind and he never links this ability to perception or sensation. In the Introduction to the Leviathan he notes that 'whosoever looketh into himself, and considereth what he doth, when he does think, opine, reason, hope, fear, \&c, and upon what grounds; he shall thereby read and know, what are the thoughts, and Passions of all other men, upon the like occasions' (see Hobbes 2012, ii, 18). And Descartes obviously played a huge role in the establishment of an introspective methodology in the early modern period.

42

Locke's library contained both the Principles and A Discourse Concerning the Gift of Prayer (1690). See Harrison and Laslett 1971, 264. Additionally, Locke's notebooks show that he had purchased An Essay Toward a Real Character (1668) and The Discovery of a World in the Moone (1638). See Williamson 1894, 225-226. 
early drafts of the Essay date from 1671, four years before the publication of the Principles. And it is clear from these drafts that inner sense already plays a key role in Locke's philosophy of mind and that he was already predisposed to analyze the will in terms of first-personal experiences. ${ }^{43}$

But even if the Principles did not influence the Essay, we can still ask about connections between Wilkins and Locke. The two men almost certainly knew one another personally, though it seems unlikely that they were close. They spent overlapping years in Oxford and were both active participants in a number of natural philosophical circles there. As Robert Frank has shown, the personal connections between members of these groups were extremely close and overlap in membership between different groups was extensive. ${ }^{44}$ Locke and Wilkins also would have had ample opportunity to meet through their involvement with the early years of the Royal Society in London. Both men served on at least one Royal Society committee together. ${ }^{45}$ At the very least, the two would have had a large number of mutual acquaintances. As McColley puts the point: 'Both men breathed the same air, and were closely identified with the English scientific renaissance of the seventeenth century'. ${ }^{46}$

43 For inner sense see Draft A, $\$ 2$ which begins 'The other fountaine of all our knowledg though it be not sense, yet is some thing very like it \& may properly enough be called sensation \& is noething but the experience of the operations of our owne minds'. Locke 1990, 7. See also the similar presentation at Draft B, 19 (Locke 1990, 129). For volition see Draft B, §4: 'what \& how many simple primary Ideas we have belonging to spirit, \& here I thinke we have also two viz perception or knowledg or thinking and a power of voluntary motion. i e a power at pleasure to move its self $\&$ at least some other bodys. These by reflection we finde in our selves within as by our sense we finde Extension \& cohæsion of parts in things without us', Locke 1990, 209-10. See also 208: 'by the simple Ideas we have taken from those operations of our owne minds we experiment dayly in our selves, as thinking understanding Willing knowing \& power of motion' (emphasis added).

44

Frank 1980.

45

Shapiro 1969, 202.

46

McColley 1938, 643. 
Harris suggests that Locke's emphasis on experience and careful observation of the mind may be related to the experimental approach to natural philosophy being developed in Britain at the time. $^{47}$ This seems to me correct. And here is where the connection between Locke and Wilkins on inner sense and volition becomes very interesting. Both men were steeped in this culture of experiment; indeed, the Royal Society committee on which they served together was the one devoted to experimentation. ${ }^{48}$ So an examination of Wilkins's views has the potential to help us better understand the connection between Locke's project in the Essay and the methodological approach to nature which was at the heart of the early Royal Society. Reading Wilkins helps us to understand that Locke was not alone in believing that the mind was a suitable subject for this method of inquiry. In fact, Wilkins shows us just how natural an 'experimental' philosophy of mind would have been for someone in Locke's position.

For further elucidation of this point we can look to Robert Boyle. Boyle was a close acquaintance of both Wilkins and Locke. And he, of course, was influential in both the natural philosophy circles of Oxford in the 1660s and in the establishment and early years of the Royal Society in London. He was, to borrow McColley's phrase, another who 'breathed the same air' as Locke and Wilkins. The following two quotes come from passages in which Boyle had cause to mention the human will:

for tho men know not how to reconcile the Liberty of mans will, with the infallible knowledge that God has of those Actions that flow from it, yet they have unanimously judged it reasonable to believe both Free-will and Prescience; the former, because they felt it in themselves; and / the later, partly because the fore-knowledge of things being manifestly a perfection,

\footnotetext{
47 See Harris 2005, 2-4.

48 See Shapiro 1969, 202.
} 
ought not to be denyed to God, whom they looked upon as a Being supremely perfect. ${ }^{49}$

But how a certain fore-knowledg can be had of contingent things, and such as depend upon the free will of man, is that which many great wits that have solicitously tryed, have found themselves unable clearly to comprehend, nor is it much to be admired that they should be puzled to conceive how an infinitely perfect Being should want Prescience, or that their will should want that liberty, whereof they feel in themselves the almost perpetual exercise. ${ }^{50}$

It seems that for Boyle as well it was natural to appeal to a robust inner sense and to believe that this inner sense furnished us with the appropriate materials for an investigation of the will and its workings.

Given all this, I think it is possible to recognize that the parallels between Wilkins and Locke pointed to in this paper are more than a mere historical coincidence. Early members of the Royal Society were eagerly engaged in a close observation of nature's workings and developed a methodology and set of empirical values to aid in that observation. But a number of their members recognized that it was possible to turn their gaze inward and subject themselves to the same careful scrutiny. And this forms a valuable piece of context for the understanding of Locke's project in the Essay and his commitment to the 'Historical, plain Method'.

49

Boyle 1999-2000, ix, 419-20 (emphasis added).

50

Boyle 1999-2000, ix, 368-69 (emphasis added).

51 We ought to note as well a parallel between the views expressed by Boyle in these passages and an oft-quoted passage from one of Locke's letters to Molyneux: 'For I own freely to you the weakness of my understanding, that though it be unquestionable that there is omnipotence and omniscience in God our maker, and I cannot have a clearer perception of any thing than that I am free, yet I cannot make freedom in man consistent with omnipotence and omniscience in God, though I am as fully perswaded of both as of any truths I most firmly assent to'. Locke to W. Molyneux, 20 January 1693, in Locke 1976-9, iv, 625-26. 


\section{Conclusion}

The goal of this paper has been to show the similarity between the theories of the mind presented by John Wilkins and John Locke. Specifically, I have shown that Wilkins and Locke have very similar views with respect to inner sense and with respect to voluntary action. Both thinkers agree that inner sense provides us access to the contents and operations of our minds. And both thinkers agree that our experiences of willing should provide the starting point for our theories of the will. I have suggested that this first similarity helps to explain the second. I have also attempted to use this parallel between Locke and Wilkins to spell out the relationship between Locke's Essay and the natural philosophy of the time.

Iowa State University ${ }^{52}$

52 I am very grateful to Alan Nelson for helpful feedback on an earlier draft of this work. Two anonymous referees and the editor of this journal all made very helpful suggestions which greatly improved the paper; I'm grateful to them. Thanks also to Dan Ferguson for help with the Greek passages in the Principles. The bulk of this paper was written during the course of a generous Summer Research Fellowship from the Graduate School of the University of North Carolina. I also wish to thank the wonderful staff of the Leeds Library, where much of the paper was written. 


\section{REFERENCES}

Aubrey, J. 1982. Brief Lives. R. Barber [ed.] Woodbridge: The Boydell Press.

Boyle, R. 1999-2000. The Works of Robert Boyle. M. Hunter and E.B. Davis [eds.] 14 vols., London: Pickering \& Chatto.

Dawson, H. 2007. 'A Ridiculous Plan: Locke and the Universal Language Movement', Locke Studies 7: 137-58.

Feingold, Mordechai. 1997. 'The Mathematical Sciences and New Philosophies', in Nicholas Tyacke [ed.] The History of the University of Oxford: Volume IV Seventeenth-Century Oxford. Oxford: Clarendon Press.

Ferreira, M. J. 1986a. 'Locke's 'Constructive Skepticism'-A Reappraisal', Journal of the History of Philosophy 24: 211-22.

Ferreira, M. J. 1986b. Scepticism and Reasonable Doubt: The British Naturalist Tradition in Wilkins, Hume, Reid, and Newman. Oxford: Oxford University Press.

Frank, Robert. 1997. 'Medicine', in Nicholas Tyacke [ed.] The History of the University of Oxford: Volume IV Seventeenth-Century Oxford. Oxford: Clarendon Press.

Frank, R. G. 1980. Harvey and the Oxford Physiologists: A Study of Scientific Ideas. Berkeley: University of California Press.

Gertler, B. 2011. 'Self-Knowledge', The Stanford Encyclopedia of Philosophy (Spring 2011 Edition), Edward N. Zalta (ed.)

Harris, J. A. 2005. Of Liberty and Necessity: The Free Will Debate in Eighteenth-Century British Philosophy. New York: Oxford University Press.

Harrison, J. and Laslett, P. 1971. The Library of John Locke. Oxford: Clarendon Press.

Henry, J. 2000. 'Wilkins, John (1614-1672)', in A. Pyle [ed.] Dictionary of Seventeenth-Century British Philosophers. Volume II. Bristol: Thoemmes.

Henry, J. 2004. 'Wilkins, John (1614-1672)', in H.C.G. Matthew and B. Harrison [eds.] Oxford Dictionary of National Biography. Oxford: Oxford University Press.

Hobbes, T. 2012. Leviathan. N. Malcolm [ed.] 3 vols., Oxford: Clarendon Press.

Hobbes, T. and Bramhall, J. 1999. On Liberty and Necessity. V. Chappell [ed.] Cambridge: Cambridge University Press.

Kulstad, M. A. 1984. 'Locke on Consciousness and Reflection', Studia Leibnitiana 16: 143-67. 
Lähteenmäki, V. 2008. 'The Sphere of Experience in Locke: The Relations Between Reflection, Consciousness, and Ideas', Locke Studies 8: 59100.

Locke, J. 1990. Drafts for the Essay Concerning Human Understanding, and Other Philosophical Writings, volume 1. P. H. Nidditch and G. A. J. Rogers [eds.] Oxford: Clarendon Press.

Locke, J. 1976-. The Correspondence of John Locke. E. S. de Beer [ed.] 8 vols., Oxford: Oxford University Press.

Locke, J. 1975. An Essay concerning Human Understanding. P. H. Nidditch [ed.] Oxford: Clarendon Press.

LoLordo, A. 2012. Locke's Moral Man. New York: Oxford University Press.

McAdoo, H. R. 1965. The Spirit of Anglicanism: A Survey of Anglican Theological Method in the Seventeenth Century. New York: Scribner.

McColley, G. 1938. 'John Wilkins-A Precursor of Locke', Philosophical Review 47: 642-43.

Mishori, D. 2004. 'Locke on the Inner Sense and Inner Observation', Locke Studies 4: 145-81.

Sams, H. W. 1943. 'Reflection', Philosophical Review 52: 400-8.

Scharp, K. 2008. 'Locke's Theory of Reflection', British Journal for the History of Philosophy 16: 25-63.

Shapiro, B. 1969. John Wilkins, 1614-1672: An Intellectual Biography. Berkeley, University of California Press.

Slaughter, M. M. 2010. Universal Languages and Taxonomy in the Seventeenth Century. New York: Cambridge University Press.

Spurr, J. 1988. "Latitudinarianism" and the Restoration Church', Historical Journal 31: 61-82.

Theil, U. 2011. The Early Modern Subject: Self-Consciousness and Personal Identity from Descartes to Hume. New York: Oxford University Press.

Thompson, J. 1980. 'Wilkins, Locke, and Restoration Concepts of Language', Interpretations 12: 76-91.

Williamson, G. 1894. 'John Locke's Pocket Book', New Review 10: 223 31.

Yaffe, G. 2000. Liberty Worth The Name: Locke on Free Agency. Princeton: Princeton University Press.

Yolton, J. 1956. John Locke and the Way of Ideas. Oxford: Oxford University Press.

Yolton, J. 1983. Thinking Matter: Materialism in Eighteenth-Century Britain. Minneapolis: University of Minnesota Press. 